\title{
The problem with 'radicalization', the remit of 'Prevent', and the need to refocus on terrorism in the UK
}

\author{
By Anthony Richards
}

\section{Introduction}

On $7^{\text {th }}$ July 2010 International Affairs, the BBC's World Tonight, and the Economic and Social Research Council (ESRC) hosted a conference at Chatham House, London entitled 'The London bombings five years on: reflections on the future of counterterrorism', and a Special Issue of International Affairs was published to mark the anniversary. ${ }^{1}$ The previous day, the Royal United Services Institute (RUSI) and the ESRC hosted a joint workshop 'Radicalization: Applying the lessons from research'. Both events were interesting and informative but in a way that revealed an uncomfortable truth: that we don't know, nor, it appears, are we ever likely to know, why some young men resort to violent extremism and others do not. Nor, it seems, has there been any consistent notion as to what is meant by 'radicalization', with the last five years providing a legacy of confusion as to what forms of 'radicalization' should be the focus of a counter-terrorism strategy.

The following argues that we should now question the utility of using 'radicalization' as the focus of response. Because its use logically implies that there should be a 'counter-radicalization' response it has helped to facilitate a 'Prevent' strand that has confusingly oscillated between tackling violent extremism in particular to promoting community cohesion and 'shared values' more broadly. Thus, while there have been significant tactical successes in thwarting terrorist attacks since $7 / 7$, this lack of clarity as to who the radicalized are and what Prevent is precisely supposed to address has left a sense of strategic drift. This article argues that the focus of counter-terrorism strategy should be on countering terrorism and not on the broader remit implied by wider conceptions of radicalization. This is certainly not to diminish the importance of contextual or 'root cause' factors behind terrorism, but, if it is terrorism that is to be understood and countered, then such factors should be

\footnotetext{
${ }^{1}$ International Affairs, Volume 86, Number 4, July 2010.
} 
viewed within the terrorism - counter-terrorism discourse and not a radicalization - counter-radicalization one.

\section{The Problem with 'Radicalization'}

Rather than being an abstract exercise of little practical utility, and if a concept like radicalization has been used as the focus for response, establishing what is meant and understood by it, and what its parameters are, is imperative if responses are not to become confused or convoluted. Yet, this is precisely what has happened. It has been unclear as to who the 'radicalized' refers to, and as a result the remit of counter-terrorism or 'counter-radicalization' has also lacked clarity. Of course, radicalization is itself a derivative of radical which is actually seen as positive in many contexts - for example, our mainstream political parties often boast of radical manifestos. It is also worth noting that we didn't use the term radicalization in Northern Ireland as the terrorist threat emerged there in the late 1960s and early 1970s. Indeed, 'as late as the early 2000 's, hardly any reference to radicalization could be found in the academic literature on terrorism and political violence'. ${ }^{2}$

Who, then, are the radicalized? Are they just those who engage in violent extremism (and here one might prefer to use the term violent radicalization). Or are they also those who support violent extremism, or those who understand why people become violent? Are they those who disapprove of violent extremism in this country but who support the Taliban in Afghanistan and Pakistan? Demos, for example, in recent empirical research of what it called 'non-violent radicals' and young Muslims in general, found that there was widespread support among such radicals and young Muslims for Iraqi and Afghan people 'defending themselves' from 'invaders'. ${ }^{3}$

The Research, Information and Communications Unit (RICU), based in the Office for Security and Counter Terrorism, undertook qualitative research that included eleven focus groups and ten in-depth interviews of British Pakistani,

\footnotetext{
${ }^{2}$ Neumann, P., Introduction, Perspectives on Radicalization and Political Violence, International Centre for the Study of Radicalization and Political Violence, January 2008, p. 3, available at: http://icsr.info/publications/papers/1234516938ICSRPerspectivesonRadicalization.pdf .

${ }^{3}$ Bartlett, J., Birdwell, J., King, M., the edge of violence, a radical approach to extremism, Demos, April $16^{\text {th }}$ 2010, p.11, available at: http://www.demos.co.uk/files/Edge of Violence - web.pdf?1271346195 (accessed on August $4^{\text {th }}$ 2010).
} 
Bangladeshi and Somali people and found that: 'Whilst they might reject the means adopted by terrorists, they sympathised with the causes [injustice and oppression faced by Muslims around the world] allegedly espoused by terrorists and felt they had legitimate grievances' ${ }^{4}$ Are these people radicalized? Are people radicalized if they think that Islam is incompatible with democracy, or if they disapprove of the use of violence but strive for the application of sharia law in the UK, or support the idea of an Islamic caliphate? ${ }^{5}$ To what extent, then, is the focus just on behaviour or is there also a focus on ideas and what people think?

Interestingly, Contest 2, the latest version of the UK's counter-terrorist strategy, has defined radicalization as 'the process by which people come to support violent extremism and, in some cases, join terrorist groups' ${ }^{6}{ }^{6}$ This definition implies that radicalization is inextricably linked to violence. Yet Demos noted that 'the last decade in particular has also seen a growth in many types of what it called non-violent radicalization' [italics added] and argued that 'a successful counter-terrorism strategy must be based on a clear understanding of these distinct forms of radicalization'?

If the indeterminate scope of radicalization (and therefore of counterradicalization) serves to confuse what the remit of response should be, neither does the use of the term add value as to why people become terrorists or what the trajectory into terrorism might be. Just as there is no one path into terrorism, there are no commonly understood metrics for radicalization that may give some clue as to when and why individuals cross the threshold from holding

\footnotetext{
${ }^{4}$ RICU, 'Counter-terror message testing', March 2010, p. 3, available at: http://tna.europarchive.org/20100419081706/http://security.homeoffice.gov.uk/news-publications/publicationsearch/comms-with-public-and-partners/RICU-research/counter-terror-message-testing?view=Binary (accessed August $4^{\text {th }}$ 2010). The 11 focus groups consisted of 6 or 7 individuals each and included men and women aged between 18-55 from 'a range of social and educational backgrounds'. The research was completed in April 2008 and was carried out in Bradford, Birmingham and London.

${ }^{5}$ The Demos report noted above (note 3 ) found that 'Certain ideas which are sometimes associated with terrorism were, in fact, held by large numbers of people who renounced terrorism. Many radicals, and indeed young Muslims, supported the application of Sharia law and the Caliphate - but usually in an aspirational or nostalgic sense', p. 11.

6 'Pursue, Prevent, Protect, Prepare', The United Kingdom's Strategy for Countering International Terrorism', March 2009, p. 11, available at: http://webarchive.nationalarchives.gov.uk/20100418065544/http://security.homeoffice.gov.uk/newspublications/publication-search/contest/contest-strategy/contest-strategy-2009?view=Binary (accessed August $4^{\text {th }}$ 2010).

${ }^{7}$ The Demos report (note 3) describes non-violent radicalization as 'the process by which individuals come to hold radical views in relation to the status quo but do not undertake, or directly aid or abet terrorist activity' (p. 8).
} 
'radical' views into becoming violent extremists. Githens-Mazer and Lambert cite the case of two brothers, where, due to the greater exposure to 'key ideas and concepts', it would appear that one of the brothers would be more likely to cross this threshold when in fact it was the other brother that attempted to commit a terrorist attack. 'Conventional wisdom' on radicalization, they argue, fails to explain why 'identity issues and exposure to 'extremist' ideas' are causal factors in one case but not the other. ${ }^{8}$ But why use 'radicalization' as the focus of attention instead of terrorism? The former is commonly referred to as a process ${ }^{9}$ but individual engagement with terrorism has also been viewed as such. ${ }^{10}$ While there is, therefore, little discernible added value in using 'radicalization' to enhance our knowledge as to why people become terrorists, it has, however, served to blur the counter-terrorist response. For, while becoming a terrorist should unequivocally be of concern to those engaged in counterterrorism, becoming 'radicalized' may not necessarily be.

This is not to argue that 'radicalization' cannot or does not lead to terrorism or, indeed, to deny that becoming a terrorist is itself, of course, a form of radicalization. Moreover, the notion that the focus for counter-terrorism should be narrower than that implied by radicalization is certainly not to diminish the importance of contextual or root 'cause' factors in understanding why terrorism takes place. But, as it is terrorism that we should be concerned with, then these factors should be considered for their causal impact on terrorism, or on why somebody becomes a terrorist, and not on broader and more opaque notions of radicalization. ${ }^{11}$

\footnotetext{
${ }^{8}$ Githens-Mazer, J., and Lambert, R., 'Why conventional wisdom on radicalization fails', International Affairs, Vol. 86, No. 4, July 2010, p. 894.

${ }^{9}$ See, for example: European Commission's Expert Group on Violent Radicalization, Radicalization Processes Leading to Acts of Terrorism, May $15^{\text {th }} 2008$, available at:

http://www.rikcoolsaet.be/files/art ip wz/Expert\%20Group\%20Report\%20Violent\%20Radicalization\%20FIN AL.pdf (accessed August 21 $1^{\text {st }} 2010$ ); Ackerman G., 'Homegrown Radicalization in the West', Peace and Security Summit, International Centre for the Study of Radicalization and Political Violence, June $30^{\text {th }}$-July $1^{\text {st }}$ 2010, summary available at:

http://www.icsr.info/events/conferences/downloads/1280838419HomegrownRadicalizationintheWest.pdf (accessed August 21st 2010).

${ }^{10}$ See, for example, Taylor and Horgan's work on terrorism as a process in Taylor, M., and Horgan, J., A 'Conceptual Framework for Addressing Psychological Process in the Development of the Terrorist', Terrorism and Political Violence, Vol. 18, No. 4, December 2006, pp. 585-601.

${ }^{11}$ See, for example, Crenshaw, M., 'The Causes of Terrorism', Comparative Politics, Vol. 13, No. 4 (July, 1981) and Bjorgo, T.,(ed.), Root Causes of Terrorism, Routledge, 2005.
} 


\section{The Remit of Prevent}

Because being radicalized has often been perceived as the way people think as well as the way they act, it has helped to facilitate a convoluted response that has oscillated between the more narrow goal of preventing violent extremism and the much wider aspiration of promoting societal cohesion and 'shared values', embodied in the broad remit of Prevent. These wider goals are not be confused, however, with engaging with communities in general in order to counter terrorist threats, and in countering the narrative of violence that $\mathrm{Al}$ Qaeda preaches - both key elements of a counter-terrorist response but very different to the wider goals of societal cohesion and shared values respectively.

The broad remit of Prevent is not something that has recently emerged. Although it has undergone adaptations and a wider focus in recent times, the July 2006 counter-terrorist strategy document, which was the culmination of the government's long term counter-terrorist strategic thinking from early 2003, itself laid the seeds for the ambiguity surrounding precisely what it was supposed to achieve. The document argued that 'the first area of action to counter radicalization lies in addressing structural problems in the UK and elsewhere that may contribute to radicalization'. ${ }^{12}$

It placed firm emphasis on tackling 'disadvantage' and 'inequalities', and improving Muslim educational performance, employment opportunities, and housing conditions. It also stressed the need for increasing community cohesion and strengthening community integration through, for example, the formation (in June 2006) of the Commission on Integration and Cohesion which was to tackle segregation, barriers to cohesion and integration, and to work out how local communities can be 'empowered to tackle extremist ideologies'. ${ }^{13}$

The assumption appeared to be that tackling longstanding structural issues to do with equality, integration and societal cohesion would help to resolve the terrorist problem. While there was a robust defence of the UK's role abroad in the strategy there was very little explicit acknowledgement of the impact of US and UK foreign policy on domestic security. The sense in the document was that, through the aim of addressing these internal 'structural' issues, there was an impetus towards internalising the sources of radicalization. To take this

\footnotetext{
12 'Countering International Terrorism: The United Kingdom's Strategy', July 2006, p. 11, available at: http://na.europarchive.org/20100419081706/http://security.homeoffice.gov.uk/news-publications/publicationsearch/contest/contest-strategy-2006? view=Binary (accessed August $5^{\text {th }} 2010$ )

13 'Countering International Terrorism: The United Kingdom's Strategy', July 2006 (note 12).
} 
further one could argue, therefore, that the genesis for such a broad remit for 'Prevent' lay in being in denial about the impact of foreign policy on the domestic terrorist threat and in fostering the belief in the significance of internal factors as underpinning radicalization.

A good example of how this broader remit for Prevent has subsequently been disseminated by the government has been in its guidance for the Higher Education sector in relation to violent extremism. In January 2008 'Promoting good campus relations, fostering shared values and preventing violent extremism in Universities and Higher Education Colleges' was produced. ${ }^{14}$ Although, at the time of writing, this is the current guidance (available on the Department for Business Innovation and Skills website) the previous Labour government had produced a further document in February 2009 entitled: 'The Role of Further Education Colleges in Preventing Violent Extremism: Next Steps'. The document argued that:

'Absolutely key to this effort [of enabling communities 'to resist extremist influence and root out terrorism'] is our quest to develop our sense of shared values: the values that bind communities together. These values belong to everyone in Britain ... it is absolutely critical that institutions embody these values of openness, free debate and tolerance'. ${ }^{15}$

A commitment to shared values, championed by former Communities Secretary Hazel Blears, was now too seen as an integral part of responding to terrorism. The guidance also announced the formation of the 'Community Cohesion and Preventing Violent Extremism Champion Principals Group' which was to 'build a greater awareness of the potential contribution that the FE college sector can make to promoting community cohesion and preventing violent extremism in all its forms. ${ }^{16}$ And the report that described the responses of the consultation process (that preceded the 'Next Steps' report) was entitled 'The Role of

\footnotetext{
${ }^{14} \mathrm{Available}$ at: http://www.bis.gov.uk/assets/biscore/corporate/migratedd/publications/e/extremismhe.pdf (accessed August 5th 2010).

15 'The Role of Further Education Colleges in Preventing Violent Extremism: Next Steps', February 2009, p. 3, available at:http://www.bis.gov.uk/assets/biscore/corporate/migratedD/publications/1/17193_DIUS_Next_Steps (accessed August $6^{\text {th }}$ 2010).

16 'The Role of Further Education Colleges in Preventing Violent Extremism: Next Steps', February 2009, p. 3 (note 15).
} 
Further Education Providers in Promoting Community Cohesion, Fostering Shared Values and Preventing Violent Extremism'. ${ }^{17}$

One of the respondents in this consultation process, the Runnymede Trust, raised the concern that preventing violent extremism and community cohesion were being conflated and noted 'the ease with which the notion of community cohesion has become intertwined with the wider Government priority of combating violent extremism'. It also argued that as a result there was a danger of 'community cohesion being seen as something that only specific ethnic or faith groups would be required to do' and it 'would fully recommend dissociation between the concepts of cohesion and prevention of terrorism if positive inter-cultural and interfaith work is to practically occur'. ${ }^{18}$

The Communities and Local Government Select Committee, in its assessment of Prevent, was also critical, questioning the:
'appropriateness of the Department of Communities and Local Government - a Government department which has responsibility for promoting cohesive communities - taking a lead role in counter-terrorism initiatives. Prevent risks undermining positive cross-cultural work on cohesion and capacity building to combat exclusion and alienation in many communities. ${ }^{19}$

The Committee also argued that 'There is a sense that Government has sought to engineer a 'moderate' form of Islam, promoting and funding only those groups which conform to this model' ${ }^{20}$ As a corollary to promoting 'shared values' counter-terrorism has also therefore been concerned with strengthening mainstream voices while apparently denying funding to others. This raises a serious difficulty for those who believe that there is merit in the idea that

\footnotetext{
${ }^{17}$ Consultation report, February 2009, available at

http://www.education.gov.uk/consultations/downloadableDocs/FE_violent_extremism_consultation_response.p df (accessed August 5th 2010).

${ }^{18}$ The Runnymede Trust, 'The Runnymede Trust Response To The Role of Further Education Providers in Promoting Community Cohesion, Fostering Shared Values and Preventing Violent Extremism', May 6th 2008, available at: $\underline{\text { http://www.runnymedetrust.org/uploads/policyResponses/ComCohesionFE_response.pdf }}$ (accessed August $5^{\text {th }} 2010$ ).

${ }^{19}$ Communities and Local Government Committee, Preventing Violent Extremism, March $30^{\text {th }} 2010$, p. 3 , available at: http://www.publications.parliament.uk/pa/cm200910/cmselect/cmcomloc/65/65.pdf (accessed August 16th 2010).

${ }^{20}$ Communities and Local Government Committee, Preventing Violent Extremism, March $30^{\text {th }} 2010$, p. 4, (note 19).
} 
effective radical (but non violent) channels of political expression need to be developed as alternative avenues to violent extremism. The Demos report referred to above, for example, argued that, 'non violent radicals might sometimes be powerful allies' and from its research noted that (although there are limits to what self-policing can achieve) 'some in the community, including radicals, have come into contact with individuals contemplating violent acts, and successfully dissuaded them. ${ }^{21}$ It argued, moreover, that:

'al-Qaeda inspired terrorism in the West shares much in common with other counter-cultural, subversive groups of predominantly angry young men. Being radical and rebelling against the received values of the status quo is an important part of being young. Ways must be found to ensure that young people can be radical, dissenting, and make a difference, without it resulting in serious or violent consequences ... Government and Muslim community groups should create and encourage programmes that offer exciting alternatives to al-Qaeda. A significant proportion of young Muslims - like many young people - will want to dissent and rebel, and the idea of being part of an international jihadi movement can be exhilarating. Governments must be more radical and daring in devising ways of engaging young people in non-violent alternatives that respond to this desire. ${ }^{22}$

The idea of opening up radical but non violent avenues for political expression again questions the utility of the term 'radicalization' (and broader conceptions of it) as the focus of a counter-terrorism response. Perhaps the empirical research of Horgan best illustrates this. Arguing for the need for greater conceptual clarity, he found that:

'the disengaged terrorist may not necessarily be ... 'deradicalized' at all ... In fact, in the sample of former terrorists I interviewed from 2006 to 2008, while almost all of the interviewees could be described as disengaged, the vast majority of them could not be said to be 'deradicalized. ${ }^{23}$

\footnotetext{
${ }^{21}$ Demos, p. 12 (note 3).

${ }^{22}$ Demos, p. 15 (note 3).

${ }^{23}$ Horgan, J., 'Individual disengagement: a psychological analysis', in Bjorgo, T., and Horgan, J., Leaving Terrorism Behind, Routledge 2009, p. 27.
} 
Thus, what in counter-terrorism and security terms could be seen as a success would in deradicalization (or counter-radicalization) terms be seen as an abject failure. Yet, in preventing violent extremism it is surely the former that we should be concerned with.

If the wider remit of Prevent has been problematic for those engaged in community cohesion, one might expect that there has been some kind of tradeoff in favour of counter-terrorism. Yet, going beyond terrorism or violent extremism and towards radicalization as a focus for response has, for many, stigmatised communities who may have little sympathy for violent extremism. The CLG Select Committee, having received over seventy responses in its research on the effectiveness of Prevent, warned that:

'Allegations of 'spying', 'intelligence gathering' and 'surveillance' under the Prevent programme are widespread' and that 'Muslim communities have felt unfairly targeted and branded as potential terrorists. The strategy has contributed to a sense of frustration and alienation amongst Muslims which may increase the risk of making some individuals more vulnerable to radicalization. ${ }^{24}$

The Demos report above argued that 'Assuming that radical views constitute the base of the terrorist pyramid can allow for counter-radicalization strategies against large numbers of people who object entirely to al Qaeda's methods'. ${ }^{25}$ In response to the government's guidance to Universities and Higher Education colleges one Deputy Vice Chancellor was concerned that the proposals tended to 'set Muslims apart as having a particular propensity for violent extremism'26, while the Demos report concluded that:

'...mission drift must be avoided. Prevention work should be limited to interventions where there is a clear, identified danger of groups or individuals undergoing radicalization to violence. Broader social concerns within Muslim communities, such as discrimination, integration or socio-

\footnotetext{
${ }^{24}$ CLG Committee report, pp. 11-17 (note 19).

${ }^{25}$ Demos, p.13 (note 3 ).

${ }^{26}$ Maughan Brown, D., 'Disingenous, Patronising and Dangerous', guardian.co.uk, February 19 ${ }^{\text {th }} 2007$, cited in The Runnymede Trust, The Runnymede Trust Response To The Role of Further Education Providers in Promoting Community Cohesion, Fostering Shared Values and Preventing Violent Extremism, May 6th 2008 (http://www.runnymedetrust.org/uploads/policyResponses/ComCohesionFE_response.pdf), article available at: http://www.guardian.co.uk/education/2007/feb/19/highereducation.uk1 (accessed August 5th 2010).
} 
economic disadvantage, should not be part of a counter-terrorism agenda, as this serves to isolate communities. ${ }^{27}$

The danger of stigmatising communities and then to hurriedly address this fear through politically correct initiatives has served to entrench (rather than reign back) the scope of the Prevent agenda. This has been done, for example, by reassuring Muslim communities that contemporary 'far right' and animal rights extremism in the UK have now also become the focus of concern, alongside but separate to Prevent. ${ }^{28}$ Little wonder that further confusion has ensued as 'we get vaguer in our targeting ... and yet we are sending out completely the wrong messages, both to the Muslim community who may think they are being tarred with a particular brush and to perhaps the wider community who are puzzled about what this programme is actually about'. ${ }^{29}$

\section{The notion of 'vulnerability'}

Along with the indeterminate scope of 'radicalization' is another label that lends itself to the broader remit of Prevent - that is the uncontested assumption widely disseminated by the government that actually the threat the UK is facing is from vulnerable people, in particular those 'vulnerable to violent extremism'. ${ }^{30}$ Again, like the 'radicalized', the metric for determining who is vulnerable to violent extremism, or what makes them vulnerable, is difficult to determine with any confidence. Yet, aside from this, why is it that those who aim to commit terrorist acts are assumed to be vulnerable to violent extremism the idea that they have succumbed to (violent) extremist ideologies and that they need guidance so that they can be rescued from the manipulation of others (online or otherwise), and that they would not carry out such acts of their own volition. Hence the government's 'intention to provide early support to those who are being drawn into offending' (italics added). ${ }^{31}$

\footnotetext{
${ }^{27}$ Demos report, p. 15 (note 3).

${ }^{28}$ See 'Delivering the Prevent Strategy: An Updated Guide for Local Partners', August 2009, available at: http://www.dcsf.gov.uk/violentextremism/preventstrategy/downloads/2009\%20Updated $\% 20$ guide $\% 20$ to $\% 201$ oc al\%20partners.pdf (accessed August 11 ${ }^{\text {th }}$ 2010).

${ }^{29}$ Quilliam, cited in CLG Committee report, p. 21 (note 19).

${ }^{30}$ In the Contest 2 strategy document alone the words vulnerable and vulnerability (to describe those individuals vulnerable to violent extremism) were used no less than a total of 32 times (note 6).

${ }^{31}$ Contest 2, p. 89 (note 6).
} 
But were the July $7^{\text {th }}$ bombers really vulnerable? The conviction in Siddique Khan's own words certainly did not suggest this:

'Your democratically elected governments continuously perpetuate atrocities against my people all over the world. And your support of them makes you directly responsible, just as I am directly responsible for protecting and avenging my Muslim brothers and sisters. Until we feel security, you will be our targets ...We are at war and I am a soldier. ${ }^{32}$

The 7/7 bombers were reported to have apparently led 'ordinary' lives with only Germaine Lindsay described as having an 'unsettled life' ${ }^{33}$ Indeed as far back as May 2006 the Intelligence and Security Committee report into 7/7 noted that 'that the threat is as likely to come from those who appear well assimilated into mainstream UK society, with jobs and young families, as from those within socially or economically deprived sections of the community. ${ }^{34}$ Nor should the case of Nicky Reilly, who had the mental age of a young child and who tried to set off an explosive device in a restaurant in Exeter in May 2008, be seen as typical or as evidence of the general vulnerability of those who engage in violent extremism. The more credible (empirical) research on terrorists suggests that they are in general psychologically no different to the rest of us. ${ }^{35}$

Such an interpretation of vulnerability matters because it lends itself to a broader spectrum of response concerned with potentially numerous 'vulnerable' individuals, and to the danger that traditionally non-security areas become securitised, such as community integration and cohesion. And if there is no

\footnotetext{
${ }^{32}$ Intelligence and Security Committee, Report into the London Terrorist Attacks on $7^{\text {th }}$ July 2005, May 2006, p. 12 (available at: http://www.cabinetoffice.gov.uk/media/cabinetoffice/corp/assets/publications/reports/intelligence/isc 7july_rep ort.pdf (accessed August 12th 2010). It is, of course, difficult to assess the degree that these international 'causes' of Muslim 'suffering' are seen as genuine grievances rather than used as propaganda in a broader ideological struggle. The fundamental point, however, is that issues in the international realm have being exploited in order to perpetrate attacks in the UK..

33 'The bombers', BBC News, (undated), available at:

http://news.bbc.co.uk/1/shared/spl/hi/uk/05/london_blasts/investigation/html/bombers.stm (accessed August 12th).

${ }^{34}$ Intelligence and Security Committee, Report into the London Terrorist Attacks on $7^{\text {th }}$ July 2005, May 2006, p. 29 (note 32).

${ }^{35}$ See, for example, Crenshaw, M., 'The Causes of Terrorism', Comparative Politics, Vol. 13, No. 4 (July, 1981), p. 390; Horgan, J., The Psychology of Terrorism, Routledge, 2005; Silke, A., 'Becoming a Terrorist', in Silke, A., (ed), Terrorists, Victims and Society, Wiley, 2003;Horgan, J., 'The Search for the Terrorist Personality', in Silke, A., (ed), Terrorists, Victims and Society, Wiley, 2003.
} 
'typical pathway to violent extremism' then the 'scope of risk-assessment is rendered potentially unlimited' for British Muslims. ${ }^{36}$

Thus, while the failure to be clear about the parameters as to what we mean by radicalization has facilitated a broader Prevent remit, so too has the notion of vulnerability to violent extremism, where the onus is apparently on communities to come together to redeem such individuals; and the vulnerability of not just individuals but communities ${ }^{37}$ logically assumes that 'community resilience' and 'community cohesion' will help to reduce the terrorist problem. ${ }^{38}$

The impetus towards thinking of terrorism in the UK as the product and outcome of 'vulnerability', however, risks misunderstanding the terrorist problem and deflecting us from what has generally been agreed in terrorism studies - that terrorism involves the perpetration of rational and calculated acts of violence. This is not to suggest that one can't be vulnerable (however defined) and rational ${ }^{39}$ at the same time but it appears that the possibility that terrorism at home could also be seen as a rational act by the perpetrators in response to British military action abroad seems to be entirely absent from governmental discourse. ${ }^{40}$ In this context one might be forgiven for thinking that the use of the term 'vulnerable' has been politically motivated to facilitate the notion that nobody in their right mind could possibly react in such a way to UK interventions in Iraq and Afghanistan, that they must have been manipulated and that those that are being drawn into violent extremism (and are therefore not acting of their own rational volition) need our help and protection for their 'recouperation' into mainstream society.

\section{Conclusion}

This article has questioned the use of 'radicalization' as a focus of response with its varying parameters. Senior police officers engaged in Prevent still confide that they are unsure as to what exactly is meant by it. Its indeterminate

\footnotetext{
${ }^{36}$ Institute for Policy Research and Development, cited in the CLG Committee report, p. 9 (note 19).

${ }^{37}$ Contest 2, p. 83 (note 6).

${ }^{38}$ See Githens-Mazer and Lambert, p. 900 (note 8), where the authors question the notion that integration and community cohesion is a relevant response to radicalization.

${ }^{39}$ Rationality is understood here to mean goal-orientated.

${ }^{40}$ For example, Prime Minister Blair was reluctant to acknowledge the impact of the Iraq war on the terrorist threat at home while Prime Minister Brown, in his justification for the British presence in Afghanistan as 'protecting British streets', consistently failed to provide a more balanced assessment that would also have acknowledged the use of Afghanistan in Al Qaeda's narrative and therefore its value in terms of propaganda and recruitment.
} 
scope has helped to facilitate the broad remit of Prevent and the 'unintended consequences' of this has meant that in some ways Prevent has actually become counterproductive. While it has complicated the task of those engaged in community cohesion, it has also generated fears of stigmatising communities. In July 2010 it was proclaimed that 'Prevent is dead: What next?' and that it had become 'as much about the government-inspired social engineering of integration as it was about stopping terrorist attacks. ${ }^{41}$ Whatever its future, and the new government's review of Prevent is pending in October 2010, it must refocus on preventing terrorism - not on fostering shared values, and not on promoting community integration or cohesion.

'Radicalization' is a relatively new concept that has very much been a 'buzzword' in counter-terrorism, policymaking and academic circles in the last five years. One often hears of the merits of 'new thinking' or 'innovative thinking' with all of its progressive connotations. But new thinking does not always mean better thinking. It transpires that radicalization has not been a particularly useful concept upon which to base a counter-terrorism response. There should now be a refocus on those that engage in, or actively support violent extremism, and not on ideas or what people think. This is not, however, to diminish broader, contextual or root cause factors behind terrorism but these factors should be considered for their causal impact on terrorism and not on broader notions of radicalization. Finally, the lesson for the new government's 'Big Society' is that counter-terrorism should not be conflated with other societal goals.

\footnotetext{
${ }^{41}$ Lambert, R., and Githens-Mazer, J., 'Prevent is dead: What next?', guardian.co.uk, July $14^{\text {th }} 2010$, available: http://www.guardian.co.uk/commentisfree/belief/2010/jul/14/prevent-counter-radicalization-terrorism-islam (accessed August 12th 2010).
} 